\title{
Emissions of greenhouse and non-greenhouse air pollutants from fuel combustion in restaurant industry
}

\author{
D. Majumdar $\cdot$ A. Chintada $\cdot$ J. Sahu $\cdot$ \\ C. V. Chalapati Rao
}

Received: 10 October 2011/Revised: 5 January 2012/Accepted: 17 April 2012/Published online: 24 April 2013

(C) Islamic Azad University (IAU) 2013

\begin{abstract}
Information on emissions from restaurant industry is limited in scientific literature. Emission inventory of greenhouse and non-greenhouse air pollutants from restaurant industry was prepared for two Class 1 Indian cities, viz. Nagpur and Raipur for 2010. Emissions were estimated from a primary database on type and amount of cooking fuel combusted in restaurant industry in the selected cities. Liquefied petroleum gas, charcoal, wood, coal, diesel and candy coal are used in this industry, first three being the major ones. Carbon dioxide emission was highest in both cities and liquefied petroleum gas, charcoal and wood were the major contributors to emissions. Total annual emissions of greenhouse gases, viz. carbon dioxide, methane and nitrous oxide were estimated to be 19,251, 27 and $1 \mathrm{Mg} \mathrm{year}^{-1}$ in Nagpur and 21,207, 34 and $1 \mathrm{Mg} \mathrm{year}^{-1}$ in Raipur, whereas total annual emissions of non-methane hydrocarbon (NMHC), carbon monoxide, total suspended particulate (TSP), sulphur dioxide, nitrogen oxides and black carbon (BC) were 96, 959, 31, 12, 19, $3 \mathrm{Mg}$ year $^{-1}$ and 87, 1141, 78, 37, 28, $6 \mathrm{Mg} \mathrm{year}^{-1}$ in Nagpur and Raipur, respectively, from all the fuels used in restaurant industry. Considering the huge growth of Indian restaurant industry in the last decade and the predicted growth in future, emissions from this industry is assumed
\end{abstract}

D. Majumdar $(\varangle) \cdot$ C. V. Chalapati Rao

Air Pollution Control Division, National Environmental

Engineering Research Institute, Nehru Marg,

Nagpur 440020, India

e-mail: d_majumdar@neeri.res.in

A. Chintada · J. Sahu

Department of Biotechnology, Kalyan P.G. College,

Bhilai Nagar, Pt. Ravishankar Shukal University,

Raipur, Chhattisgarh, India to grow and will play a major role in governing regional and national emissions in India.

Keywords Air pollution - Atmosphere - Commercial cooking $\cdot$ Energy $\cdot$ Global warming

\section{Introduction}

Indian restaurant industry has seen tremendous growth in the last several years due to growing tourism, increase in disposable income and increasing trend of dining outside (Federation of Hotels and Restaurant Associations of India 2004). Most of the Indian restaurants are in the unorganized sector while the organized restaurant market share is only about $16 \%$ of the estimated 43,000 crore (i.e. 430 billion Indian rupees or about 7.9 billion US dollars; 1 US dollar $=54.47$ Indian rupees, as on 11.3.2013) Indian restaurant Industry, which may grow up to $45 \%$ by 2015, opined National Restaurant Association of India (Financial Chronicle 2010). It is generally believed that the number of people eating outside is increasing, especially in urban areas (Pandey 2002). As per a survey (Federation of Hotels and Restaurant Associations of India 2004), $2.5 \%$ of surveyed population dined out once in a week while $1.7 \%$ dined more than once per week while 2.1 and $5.5 \%$ dined once and in a fortnight and month, respectively.

Fuel combustion generates a variety of air pollutants, notable being carbon monoxide $(\mathrm{CO})$, nitrogen oxides $\left(\mathrm{NO}_{x}\right)$, sulphur dioxide $\left(\mathrm{SO}_{2}\right)$, volatile organic carbon (VOCs), poly-aromatic hydrocarbons (PAHs), formaldehyde, particulate matter, black carbon (BC), etc. (Zhang and Smith 2007), apart from greenhouse gases like carbon dioxide $\left(\mathrm{CO}_{2}\right)$, methane $\left(\mathrm{CH}_{4}\right)$ and nitrous oxide $\left(\mathrm{N}_{2} \mathrm{O}\right)$ (Pearson and Palmer 2000). $\mathrm{CH}_{4}$ and $\mathrm{N}_{2} \mathrm{O}$ have much 
higher global warming potential than $\mathrm{CO}_{2}$ at all time scales, making them extremely important in earth's radiation budget. Further, $\mathrm{CH}_{4}$ along with non-methane hydrocarbons (NMHCs) and CO may contribute to the rise of regional ground-level ozone levels causing damage to human and plant life (West et al. 2006).

Various emission inventory estimates prepared for Indian cities have ignored the emissions contributed by restaurant industry, as emissions from this industry is seemingly lower than industrial or transport sectors, for example. Even, the commercial sector inclusive of restaurants has rarely been considered in the emission inventories published in scientific literature. In India, Ministry of Environment and Forests (MoEF) estimated total $\mathrm{CO}_{2}$ equivalent emission from residential and commercial/institution sector to be 139.51 million tons in 2007 (Ministry of Environment and Forests 2010), but did not specify the sub-sectors considered within commercial sector. In 1990 and 1995, Maharashtra closely followed Uttar Pradesh as the highest $\mathrm{SO}_{2}$ emitter state in India, primarily driven by use of coal in power sector and highspeed diesel (HSD), fuel oil and petrol in industrial and transport sectors (Garg and Shukla 2002). The official Indian estimate of $\mathrm{CO}_{2}$ emissions in 1994 of $817 \mathrm{Tg} \mathrm{CO}_{2}$ (terra gram $\mathrm{CO}_{2}$ ) were estimated to have grown to $1,229 \mathrm{Tg} \mathrm{CO}_{2}$ in 2005 , growing about $4 \%$ per annum (Garg et al. 2006), in which removals by land use and landuse change activities were not considered.

Emissions from restaurants may contain appreciable load of fine particle matter also apart from gaseous pollutants (Rand and Scatena 2006). A study conducted in New Jersey reported that the main source of particulate emissions may be the charbroiling equipments, with under-fired charbroiling contributing about $84 \%$ of this particulate matter (Rand and Scatena 2006). Importance of charcoal as an energy source is thus far not realized significantly, as its use is limited in household sector and industrial sector, but in restaurant industry it plays the role of a prime energy source particularly in India due to the popularity of charcoal-fired preparations. Liquefied petroleum gas (LPG), being the cleanest fuel, has lesser contribution to air pollution but may be an important contributor to carbon dioxide. In another study, a VOC like toluene was the found to be the most abundant in charcoal emissions during cooking and carbonyls like formaldehyde and acetaldehyde were found in substantial amounts (Kabir et al. 2010). Fuels like coal, wood, crop residues are appreciably more polluting per meal than liquid and gaseous fuels. Evidently, use of unprocessed solid fuels in restaurants has the potential of causing substantial air pollution.

According to Bhattacharya et al. (2002), biomass fuels are likely to continue to meet the cooking energy needs of the majority of population in the poor countries. Without doubt, a substantial amount of fuel is used in restaurant industry in India, including polluting fuels like low-grade coal, cow dung, fuelwood, coal balls, etc., especially in small cities and towns. There are numerous small eating joints, mostly mobile, who also commit serious air pollution by burning fuels like charcoal, coal, wood, kerosene, dung cakes, coal balls, LPG, diesel, etc. The fact that India is a large country with a huge population and large number of restaurants, fuel consumption and resultant air pollution from this sector is likely to be substantial. Although several emission inventories have been prepared worldwide and in India for important sectors like industry, domestic, commercial, agriculture, vehicular (Garg et al. 2001, 2006), very little or no exclusive emission estimate from fuel consumption in restaurant industry is available till date. The authors opine that restaurant industry in all medium and big cities in India are potentially big emitters of greenhouse and non-greenhouse air pollutants and this industry may be contributing heavily to the emissions of greenhouse gases and other air pollutants. Preparing all India emission inventory from restaurant industry may be a difficult task considering the lack of all India database on fuel usage in restaurants. So, as a beginning, city-based emission inventories can be attempted. This will throw light not only on the emission potential of restaurant industry of individual cities, but may also roughly indicate the emission potential of the same in the country. This industry may prove to be a significant contributor to total national emissions.

Keeping in view the lack of emission estimates from this sector in India or elsewhere, the present study was carried out to prepare an emission inventory of greenhouse gases and other air pollutants from fuel consumption in the restaurant industry for the year 2010 in two Class 1 Indian cities, namely Nagpur and Raipur, former the erstwhile capital of Maharashtra State and the later present capital of Chhattisgarh State. The study addresses the need of understanding emission potential of restaurant industry, at least on a regional basis, on which very limited information is available. The study would help in bridging the knowledge gap on the extent of contribution of restaurant industry in regional and national emissions of greenhouse and non-greenhouse air pollutants and would help in formulating necessary policy decisions on this sector.

\section{Materials and methods}

\section{Description of selected cities}

Nagpur is the erstwhile capital of the State of Maharashtra. As per Government of India classification based on city population, Nagpur with a population of 2,122,965 is 
classified as Class 1 city (Bhonsle 2010). It is the largest city in Central India and third largest by population in Maharashtra and 13th largest city in India (Bhonsle 2010). Being at the centre of India, Nagpur is at the junction for India's two major national highways viz. NH 7 and NH 6 and two Asian highways, namely AH43 and AH46 and so cater to appreciable number of people in transit (Bhonsle 2010). Nagpur's own industrial and business potential makes it an important commercial and industrial centre of India, underlining the huge importance of the restaurant industry in commerce and business. Maharashtra had 4.6 and $10.7 \%$ growth rate in trade, hotels and restaurant sector in 2001-2002 and 2002-2003 over the previous years at constant 1993-1994 prices (Government of Maharashtra, http://www.maharashtra.gov.in/english/eco Survey/ecoSurvey1/esm_e/cha05e.pdf, accessed on 8.8. 2010). Nagpur had been listed amongst the top ten $\mathrm{SO}_{2^{-}}$ emitting districts in India (Garg et al. 2001). The sectoral composition of $\mathrm{SO}_{2}$ emissions indicated a predominance of electric power generation sector (46\%). District-level analysis indicated diverse spatial distribution with the top $5 \%$ emitting districts contributing 46.5 of total national $\mathrm{SO}_{2}$ emissions (Garg et al. 2001).

On the other hand, Raipur is the present capital of State of Chhattisgarh. As per 2001 India census, Raipur had a population of 1,605,131 (Census of India 2001) and is also categorized as a Class 1 city on the basis of city population (Census of India 2001). Raipur being an important industrial city has large number of non-resident and nonpermanent population, comprising mostly of visitors on business errand and thus the restaurant industry is one of the most lucrative commercial and business aspects of this city.

There is no authentic and comprehensive database on the restaurants under organized or unorganized category in Nagpur or Raipur vis-à-vis Indian towns and cities. In the organized restaurant sector though, city-specific databases on registered restaurants are maintained by some major city municipalities, but there is no comprehensive or compiled database on number of registered restaurants in India. The city-based details on restaurants, wherever available, are limited to only name/address and sometimes the category of restaurants. There is no open access database available on kind and quality of fuel used in this sector for cooking in the selected cities in India. Moreover, the numerous mobile and semi-mobile food vendors in Indian cities and towns are hardly included in any database.

\section{Collection of fuel consumption data}

Lists of restaurants registered under respective Municipal Corporations and their addresses were collected from respective city municipality offices. 569 and 513 restaurants, respectively, under 10 and 8 municipal zones in Nagpur and Raipur were registered at the time of survey in January 2010. A preliminary survey was conducted in all the zones in Nagpur and Raipur to collect information on the listed restaurants. Finally, restaurants numbering 68 in Nagpur and 48 in Raipur, having a mix of small, medium and big ones based on the number of persons that could be served at a time, were selected for a questionnaire survey. The restaurants were so selected that they represented the whole range of fuels used in the restaurant sector of the cities. More numbers of restaurants could not be included in questionnaire survey due to limited willingness of the restaurant owners to participate in the survey. The selected restaurants in Nagpur comprised categories like A/B/C designated by the Nagpur Municipal Corporation. Information on types and amount of fuels used per day was collected through the survey undertaken in the selected registered restaurants. Based on the feedback from selected restaurants, percentage of restaurants using each fuel was calculated and probable number of restaurants using the same fuel in the entire city was estimated for calculation of annual fuel consumption (Table 1). The unregistered and mobile food vendors were not selected for this study as their number could not be reliably estimated due to their constant mobility and temporary nature.

\section{Emission calculations}

Emission of each air pollutant can be attributed to combustion of various fuels, viz. LPG, charcoal, coal, wood, candy coal and diesel that are used in restaurant industry in the selected cities. Annual consumption of a given fuel was multiplied by the specific emission factor of a pollutant for the given fuel to obtain total annual emission of the pollutant from the given fuel. To calculate total emission of a pollutant from all the fuels together, individual fuel-wise emissions were added. The following equation was used for calculating emission of an air pollutant from a source category, i.e. fuel:

$$
\begin{aligned}
\text { Emission }_{\text {air pollutant,fuel }}= & \text { Consumption }_{\text {fuel }} \\
& \times \text { EF }_{\text {air pollutant,fuel }}
\end{aligned}
$$

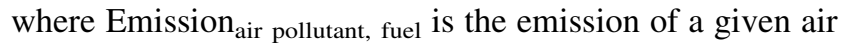
pollutant from a given fuel, Consumption fuel $_{\text {is consump- }}$ tion of the given fuel, $\mathrm{EF}_{\text {air pollutant, fuel }}$ is emission factor of a given pollutant for a given fuel

Subsequently, total emission of each pollutant from all the fuels in restaurant industry was calculated the following way: 
Table 1 Fuel consumption by restaurants in Nagpur and Raipur

\begin{tabular}{|c|c|c|c|c|c|c|c|c|c|c|}
\hline \multirow[t]{3}{*}{ Fuel $^{\mathrm{a}}$} & \multirow{2}{*}{$\begin{array}{l}\text { Percent } \\
\text { usage in } \\
\text { surveyed } \\
\text { restaurants } \\
\\
A\end{array}$} & \multirow{2}{*}{$\begin{array}{l}\text { Usage in } \\
\text { most } \\
\text { probable } \\
\text { number of } \\
\text { restaurants }\end{array}$} & \multirow{2}{*}{$\begin{array}{l}\begin{array}{l}\text { Mean } \\
\text { consumption }^{\mathrm{d}} \\
\left(\mathrm{kg} \mathrm{day}^{-1}\right)\end{array} \\
C\end{array}$} & \multirow{2}{*}{$\begin{array}{l}\begin{array}{l}\text { Annual } \\
\text { consumption } \\
\left(\mathrm{kg} \mathrm{year}^{-1}\right)\end{array} \\
D=B^{*} C^{*} 365\end{array}$} & \multirow{2}{*}{$\begin{array}{l}\text { Usage in } \\
\text { surveyed } \\
\text { restaurants } \\
(\%)^{\mathrm{b}} \\
E\end{array}$} & \multirow{2}{*}{$\begin{array}{l}\text { Usage in } \\
\text { most } \\
\text { probable } \\
\text { number of } \\
\text { restaurants }\end{array}$} & \multirow{2}{*}{$\begin{array}{l}\text { Mean } \\
\begin{array}{l}\text { consumption }^{\mathrm{d}} \\
\left(\mathrm{kg} \mathrm{day}^{-1}\right)\end{array} \\
G\end{array}$} & \multirow{2}{*}{$\begin{array}{l}\text { Annual } \\
\text { consumption } \\
\left(\mathrm{kg} \mathrm{year}^{-1}\right)\end{array}$} & \multicolumn{2}{|c|}{$\begin{array}{l}\text { Per capita } \\
\text { consumption } \\
\left(\mathrm{kg} \mathrm{year}^{-1}\right)\end{array}$} \\
\hline & & & & & & & & & Nagpur & Raipur \\
\hline & Nagpur & & & & Raipur & & & & & \\
\hline Charcoal & 70 & 398 & 20 & $29,05,400$ & 60 & 308 & 25 & $28,10,500$ & 1.4 & 1.8 \\
\hline Coal & 10 & 57 & 21 & $4,36,905$ & 25 & 128 & 35 & $16,35,200$ & 0.2 & 1.0 \\
\hline Wood & 10 & 57 & 39 & $8,11,395$ & 15 & 77 & 82 & $23,04,610$ & 0.4 & 1.4 \\
\hline LPG & 93 & 529 & 16 & $30,89,360$ & 70 & 359 & 15 & $19,65,525$ & 1.5 & 1.2 \\
\hline Diesel & - & - & - & - & 6 & 31 & $7^{\mathrm{e}}$ & $79,205^{\mathrm{f}}$ & - & $0.05^{\mathrm{f}}$ \\
\hline Candy coal & 7 & 40 & 15 & $2,19,000$ & 13 & 67 & 18 & $4,40,190$ & 0.1 & 0.3 \\
\hline
\end{tabular}

${ }^{a}$ Soybean cake is ignored as it was found in 1 restaurant only in Nagpur

b Percentage value is rounded up to the nearest whole number

c Total number of registered restaurants in Nagpur and Raipur were 569 and 513, respectively (as in February 2010)

d Average of surveyed restaurants

e Unit-L day ${ }^{-1}$

${ }^{\text {f }}$ Unit-L year ${ }^{-1}$

Emission $_{\text {air pollutant,fuels }}=\sum_{\text {fuel }}$ Emission $_{\text {air pollutant,fuel }}$

Emissions of $\mathrm{CH}_{4}$ and $\mathrm{N}_{2} \mathrm{O}$ were converted to respective $\mathrm{CO}_{2}$-equivalent emissions by multiplying with respective global warming potentials reported by IPCC (2001) for different time horizons, i.e. 20, 100 and 500 years.

Emission factors

Emission factors for all the selected pollutant-fuel combinations were compiled from scientific literature, scrutinized and suitable ones were chosen for usage in Eq. (1). India-specific emission factors have been used wherever available or otherwise, emission factors reported by Intergovernmental Panel on Climate Change (IPCC), United States Environmental Protection Agency (USEPA), US Energy Information Administration (EIA) and various researchers have been used. Emission factors were finally used as gram of pollutant per kilogram of fuel $\left(\mathrm{g} \mathrm{kg}^{-1}\right)$ for calculation and so, reported emission factors in units like $\mathrm{lb}$ $\mathrm{MMBTU}^{-1} / \mathrm{Mt} \mathrm{kL}^{-1} / \mathrm{kg} \mathrm{Mt}^{-1} / \mathrm{kg} \mathrm{TJ}^{-1} / \mathrm{kg} \mathrm{m}^{-3} / \mathrm{lbs}$ ton $^{-1} /$ $\mathrm{kg} \mathrm{kL}^{-1}$ or any other, were converted to $\mathrm{g} \mathrm{kg}^{-1}$. For solid fuels like charcoal and wood, all the emission factors were available in $\mathrm{g} \mathrm{kg}^{-1}$ and so were directly used for calculation. For another solid fuel coal, several emissions factors had to be converted to $\mathrm{g} \mathrm{kg}^{-1}$ (Table 2). Emission factors of $\mathrm{CO}_{2}, \mathrm{CH}_{4}, \mathrm{~N}_{2} \mathrm{O}, \mathrm{CO}$ and NMHC for LPG were available as $\mathrm{g} \mathrm{kg}^{-1}$ and used in toto but $\mathrm{SO}_{2}, \mathrm{NO}_{x}$ and TSP emission factors had to be converted to $\mathrm{g} \mathrm{kg}^{-1}$. Similarly for diesel, emission factors reported in various other units were converted to $\mathrm{g} \mathrm{kg}^{-1}$ by suitable calculations (Table 3 ). Conversion of all the EFs to a common unit $\left(\mathrm{g} \mathrm{kg}^{-1}\right)$ made it easier to comparatively evaluate all the emission factors used in this study.

\section{Results and discussion}

Fuel consumption scenario

Several fuels were found to be used in the restaurant sectors of the two cities and barring diesel in Raipur, all other fuels like LPG, charcoal, coal, wood and candy coal were common to both cities (Table 1). LPG and charcoal usage were more predominant in Nagpur, while in Raipur charcoal and wood were predominant. A few restaurants, more in number in Raipur than Nagpur, used a cheap and locally available fuel like coal balls, called candy coal in vernacular, which are prepared from coal dust mixed with traces of clay or silt as binders. Consumption of candy coal was more than double in Raipur than Nagpur. In Nagpur, candy coal is used in only a few small restaurants in the city outskirts, where wood is also frequently used because of its low price and easy availability from nearby villages. Diesel-run stoves were found to be used in several small restaurants in Raipur only. Very few restaurants depended on any one particular fuel for cooking; a mixture of various fuels was common in both the cities. Other common Indian household fuels like kerosene and dung cake were not found in any restaurant, although some restaurant owners 
Table 2 Emission factors for solid fuels (charcoal, wood, coal and candy coal)

\begin{tabular}{|c|c|c|c|c|}
\hline \multirow[t]{2}{*}{ Air pollutant } & \multirow[t]{2}{*}{ Charcoal $\left(\mathrm{g} \mathrm{kg}^{-1}\right)$} & \multirow[t]{2}{*}{ Wood $\left(\mathrm{g} \mathrm{kg}^{-1}\right)$} & \multicolumn{2}{|l|}{ Coal/candy coal ${ }^{\mathrm{i}}$} \\
\hline & & & Reported emission factor ${ }^{\mathrm{o}}\left(\mathrm{g} \mathrm{kg}^{-1}\right.$ unless specified) & Calculated emission factor $\left(\mathrm{g} \mathrm{kg}^{-1}\right)$ \\
\hline $\mathrm{CO}_{2}$ & $2411^{\mathrm{a}}$ & $1830^{\mathrm{d}}$ & 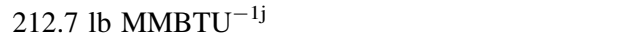 & $1875.9^{j}$ \\
\hline $\mathrm{CH}_{4}$ & $8^{\mathrm{a}}$ & $5^{\mathrm{e}}$ & $0.00141 \mathrm{lb} \mathrm{MMBTU} \mathrm{M}^{-1 \mathrm{j}}$ & $0.012436^{\mathrm{j}}$ \\
\hline $\mathrm{N}_{2} \mathrm{O}$ & $0.24^{\mathrm{a}}$ & $0.06^{\mathrm{e}}$ & $0.00326 \mathrm{lb} \mathrm{MMBTU}^{-1 \mathrm{j}}$ & $0.028752^{\mathrm{j}}$ \\
\hline $\mathrm{CO}$ & $275^{\mathrm{a}}$ & $80^{\mathrm{e}}$ & $73.7^{\mathrm{k}}$ & - \\
\hline $\mathrm{SO}_{2}$ & $0.34^{\mathrm{b}}$ & $0.48^{\mathrm{f}}$ & $16.5 \times \mathrm{S} \mathrm{kg} \mathrm{MT}^{-11}$ & 16.5 \\
\hline NMHC & $10.5^{\mathrm{a}}$ & $9^{\mathrm{e}}$ & $0.03 \mathrm{lb}$ ton $^{-1 \mathrm{~m}}$ & 0.013608 \\
\hline $\mathrm{NO}_{\mathrm{x}}$ & $2.34^{\mathrm{b}}$ & $1.4^{\mathrm{g}}$ & $2.61^{\mathrm{k}}$ & - \\
\hline TSP & $1.95^{\mathrm{b}}$ & $21^{\mathrm{g}}$ & $11.2^{\mathrm{k}}$ & - \\
\hline $\mathrm{BC}$ & $0.4^{\mathrm{c}}$ & $0.41^{\mathrm{h}}$ & $1.83^{n}$ & - \\
\hline
\end{tabular}

${ }^{a}$ Weighed average EF for India (1990-1991) (USEPA 2000a)

${ }^{b}$ Calculated for commercial charcoal use in India (Bhattacharya et al. 2000)

${ }^{c}$ Residential charcoal consumption (Parashar et al. 2005)

${ }^{d}$ IPCC default emission factor for wood (IPCC, 2006)

e Default (uncontrolled) emission factor for residential fuel combustion (IPCC, 1997)

${ }^{\mathrm{f}}$ Based on $0.04 \% \mathrm{~S}$ in wood (Smith et al. 2000) used in cookstoves (Reddy and Venkataraman 2002a; Ballard-Tremeer 1997; Ballard-Tremeer and Jawurek 1996)

g Emission factor for wood used in domestic heating (Bhattacharya et al. 2000)

${ }^{\mathrm{h}}$ Emission factor for fuelwood combustion (Reddy and Venkataraman 2002a)

${ }^{\mathrm{i}}$ Emission factors for candy coal are treated equivalent to coal as emission factor for candy coal is not available

${ }^{\mathrm{j}}$ Calculated from calorific value of bituminous Indian coal Indian coal: 4,900 kcal kg ${ }^{-1}$ or $0.01944477 \mathrm{MMBTU} \mathrm{kg}^{-1}$ (Energy Information Administration 2001; Standing Committee on Energy, Government of India, 2001 http://164.100.24.208/ls/committeeR/Energy/18th/ chapter6.htm)

${ }^{\mathrm{k}}$ EF for bituminous coal (Donaldlucas et al. 2008)

${ }^{1}$ USEPA (2000b)

${ }^{m}$ Lignite combustion derived for bituminous data, C2-C16 alkane eq. for stoker feeder (USEPA 2000b)

${ }^{n}$ EF for domestic coal (uncontrolled) (Reddy and Venkataraman 2002b)

o Percent $S$ is assumed as $1 \%$ for average Indian coal (Tiwary and Dhar 1994)

use little amount of kerosene for fuel ignition. As the kerosene stoves are too inefficient for commercial cooking and kerosene imparts its smell to food if handled poorly, these stoves are not used in restaurant sector in these two cities. Per capita consumption, calculated by using the entire city population, of all the fuels except LPG was higher in Raipur. Higher per capita charcoal, coal, wood and candy coal consumption in Raipur is a result of lower usage of LPG and dependence on these former fuels to compensate the energy deficit. Studies conducted on fuel usage in restaurants in Taiwan indicated that wood and charcoal were the major cooking fuel for restaurants and small food industries (Chaiklangmuang et al. 2008; Pinnium 2000; Suntisirisomboon and Milintale 2001 check sequence). Chaiklangmuang et al. (2008) reported that biomass and coal constituted 96 and $4 \%$ of the raw materials used for briquette preparation for usage as fuel in restaurants in Chiang Mai province in Thailand.
Inventory assessment

\section{Greenhouse gases}

Emission of $\mathrm{CO}_{2}$ from fuel combustion depends on carbon content of the fuel, e.g. roughly for each unit of energy produced, natural gas emits about half and petroleum fuels about three-quarters of the $\mathrm{CO}_{2}$ produced by coal (The Ames laboratory, US Department of Energy, http://www. ameslab.gov, accessed on 29.5.2012). Even, a clean fuel like LPG is a strong source of $\mathrm{CO}_{2}$ (USEPA 2000a). In Nagpur, annual emissions of $\mathrm{CO}_{2}, \mathrm{CH}_{4}$ and $\mathrm{N}_{2} \mathrm{O}$ were estimated to be 19,251, 27 and $1 \mathrm{Mg} \mathrm{year}^{-1}$ (mega gram per year) from all the fuels used in the restaurant industry. In both the cities, combined $\mathrm{CO}_{2}$ emission from all the fuels was substantially higher than $\mathrm{CH}_{4}$ and $\mathrm{N}_{2} \mathrm{O}$ (713 and 19,251 times in Nagpur and 624 and 21,207 times in Raipur, respectively) due to substantially higher $\mathrm{CO}_{2}$ emission factors of all the fuels (Table 4). In Nagpur, LPG 
Table 3 Emission factors for liquid fuels (LPG and diesel)

\begin{tabular}{|c|c|c|c|c|}
\hline \multirow[t]{2}{*}{ Air pollutant } & \multicolumn{2}{|l|}{ LPG } & \multicolumn{2}{|l|}{ Diesel } \\
\hline & $\begin{array}{l}\text { Reported emission factor } \\
\left(\mathrm{g} \mathrm{kg}^{-1} \text { unless specified) }\right.\end{array}$ & $\begin{array}{l}\text { Calculated emission } \\
\text { factor }\left(\mathrm{g} \mathrm{kg}^{-1}\right)\end{array}$ & $\begin{array}{l}\text { Reported emission factor } \\
\left(\mathrm{g} \mathrm{kg}^{-1} \text { unless specified) }\right.\end{array}$ & $\begin{array}{l}\text { Calculated emission } \\
\text { factor }\left(\mathrm{g} \mathrm{kg}^{-1}\right)\end{array}$ \\
\hline $\mathrm{CO}_{2}$ & $3085^{\mathrm{a}}$ & - & $2.68 \mathrm{MT} \mathrm{kL}^{-1 \mathrm{f}}$ & $3243.37^{\mathrm{g}}$ \\
\hline $\mathrm{CH}_{4}$ & $0.05^{\mathrm{a}}$ & - & $0.134396 \mathrm{~kg} \mathrm{MT}^{-1 \mathrm{~h}}$ & 0.134396 \\
\hline $\mathrm{N}_{2} \mathrm{O}$ & $0.15^{\mathrm{a}}$ & - & $0.026879 \mathrm{~kg} \mathrm{MT}^{-1 \mathrm{~h}}$ & 0.026879 \\
\hline $\mathrm{CO}$ & $15^{\mathrm{a}}$ & - & $0.95 \mathrm{lb} \mathrm{MMBTU} \mathrm{M}^{-1 \mathrm{i}}$ & $17.699^{j}$ \\
\hline $\mathrm{SO}_{2}$ & $0.01 \times \mathrm{S} \mathrm{kg} \mathrm{m}^{-3 b}$ & $0.00037^{\mathrm{b}}$ & $0.005 \mathrm{~kg} \mathrm{~kg}^{-1 \mathrm{i}}$ & 5 \\
\hline $\mathrm{NO}_{\mathrm{x}}$ & $66 \mathrm{~g} \mathrm{GJ}^{-1 \mathrm{c}}$ & $3.04^{\mathrm{c}}$ & $4.41 \mathrm{lb} \mathrm{MMBTU} \mathrm{M}^{-1 \mathrm{i}}$ & 82.16 \\
\hline NMHC & $18.8^{\mathrm{a}}$ & - & - & - \\
\hline TSP & $0.21 \mathrm{~kg} \mathrm{~m}^{-3 \mathrm{~d}}$ & $0.388^{\mathrm{d}}$ & $0.25 \mathrm{~kg} \mathrm{~kL}^{-1 \mathrm{k}}$ & $0.3025^{1}$ \\
\hline $\mathrm{BC}$ & $0.01^{\mathrm{e}}$ & - & $0.08^{\mathrm{m}}$ & - \\
\hline
\end{tabular}

${ }^{a}$ Weighed average EF for India (1990-1991) (USEPA 2000a)

b TERI (1992); S content of LPG assumed as $0.02 \%$ (Reddy and Venkataraman 2002a) and LPG sp. gr. taken as $540 \mathrm{~kg} \mathrm{~m}$

c Calorific value LPG taken as $46.1 \mathrm{MJ} \mathrm{kg}^{-1}$ (US Dept of Energy 1995)

d TERI (1992); Sp. gr. of LPG taken as $540 \mathrm{~kg} \mathrm{~m}^{-3}$

e EF for residential LPG (Reddy and Venkataraman 2002a)

${ }^{\mathrm{f}}$ Derived from reported EF for diesel fuel (No. 1 and No. 2) of $22.37 \mathrm{lb}$ gallon ${ }^{-1}$ (US Energy Information Administration 2007)

g Density of diesel taken as $826.3 \mathrm{~kg} \mathrm{~kL}^{-1}$

${ }^{\mathrm{h}}$ Calculated from IPCC (2006) reported emission factor of $3 \mathrm{~kg} \mathrm{TJ}^{-1}$ for LDO, using net calorific value (NCV) in $\mathrm{J} \mathrm{kg}^{-1}$ of the fuels reported by IEA (Treanton 2004)

${ }^{\mathrm{i}}$ USEPA AP 42 for industrial diesel engines (Eastern Research Group 1996)

${ }^{\mathrm{j}}$ Calorific value of diesel is taken as $43333 \mathrm{~kJ} \mathrm{~kg}^{-1}$ or $0.04107176 \mathrm{MMBTU} \mathrm{kg}^{-1}$

$\mathrm{k}$ TERI (1992); diesel assumed as distillate oil

${ }^{1}$ Density of diesel taken as $826.3 \mathrm{~kg} \mathrm{~kL}^{-1}$

${ }^{\mathrm{m}} \mathrm{EF}$ for diesel oil in industrial application (Reddy and Venkataraman 2002a)

had greatest contribution to $\mathrm{CO}_{2}$ emissions as LPG consumption was the highest and it has the second largest $\mathrm{CO}_{2}$ emission factor (behind diesel) amongst all the fuels. Contribution of LPG in $\mathrm{CO}_{2}$ emissions in Nagpur was $50 \%$ of the total $\left(9,531 \mathrm{Mg}\right.$ year $\left.^{-1}\right)$, followed by charcoal (7,005 Mg year $\left.{ }^{-1}, 36 \%\right)$, wood $\left(1,485 \mathrm{Mg}\right.$ year $\left.^{-1}, 8 \%\right)$, coal $\left(820 \mathrm{Mg}\right.$ year $\left.^{-1}, 4 \%\right)$ and candy coal $(411 \mathrm{Mg}$ year ${ }^{-1}, 2 \%$ ) (Fig. 1). Contribution of coal in $\mathrm{CO}_{2}$ emissions was almost four times more in Raipur than Nagpur as coal consumption was almost four folds higher in the former. Similarly, $\mathrm{CO}_{2}$ emissions from wood were also higher in Raipur than Nagpur due to its much higher consumption in the former. Total $\mathrm{CO}_{2}$ emission was higher in Raipur than Nagpur, driven by much higher consumption of coal, candy coal and wood.

Annual emissions $\mathrm{CO}_{2}, \mathrm{CH}_{4}$ and $\mathrm{N}_{2} \mathrm{O}$ were $21,207,34$ and $1 \mathrm{Mg}$ year $^{-1}$ in Raipur from all the fuels used in the restaurant industry. Charcoal was the major contributor to $\mathrm{CO}_{2}$ emissions $\left(6,776 \mathrm{Mg}\right.$ year $\left.^{-1}, 32 \%\right)$, followed by LPG (6,064 Mg year $\left.{ }^{-1}, 29 \%\right)$, wood (4,217 Mg year $\left.{ }^{-1}, 20 \%\right)$, coal (3,068 Mg year $\left.{ }^{-1}, 14 \%\right)$, candy coal (826 Mg year ${ }^{-1}$, $4 \%$ ) and diesel (257 $\mathrm{Mg}$ year $^{-1}, 1 \%$ ) (Fig. 1). Total $\mathrm{CH}_{4}$ emission was higher than Nagpur, while $\mathrm{N}_{2} \mathrm{O}$ emissions were almost at par in both cities. Charcoal combustion was the primary source of $\mathrm{CH}_{4}$ and $\mathrm{N}_{2} \mathrm{O}$ in terms of absolute emission amounts in both cities; more in Nagpur (85\%) than Raipur (66\%), substantially more than the next contributor, wood, at 15 and $34 \%$, respectively. Other fuels had near or lesser than $1 \%$ share in $\mathrm{CH}_{4}$ emissions (Fig. 1). Charcoal, LPG and wood were the primary contributor to $\mathrm{N}_{2} \mathrm{O}$ emissions, in that order, in both cities. In Nagpur, charcoal had highest share in $\mathrm{CH}_{4}$ and $\mathrm{N}_{2} \mathrm{O}$ emissions as emission coefficients for $\mathrm{CH}_{4}$ and $\mathrm{N}_{2} \mathrm{O}$ from charcoal were highest amongst all the fuels and charcoal usage was also high. But, in Raipur, charcoal had the highest share in all the three greenhouse gas emissions since its usage was much higher than all other fuels and its emission coefficient for all three gases were also high. Charcoal's contribution to $\mathrm{N}_{2} \mathrm{O}$ emissions were almost uniform in both cities at about 57-58 \%, followed by LPG (38 and $25 \%$, respectively). Raipur contributed 3 and 4 times more $\mathrm{N}_{2} \mathrm{O}$ emissions from wood and coal, respectively, than Nagpur, as the usage of these two fuels were higher in the former. Contribution of diesel in $\mathrm{N}_{2} \mathrm{O}$ emissions was lower than $1 \%$ while its contribution to $\mathrm{CH}_{4}$ emissions was even lower at $0.03 \%$ in Raipur. Total $\mathrm{CH}_{4}$ 


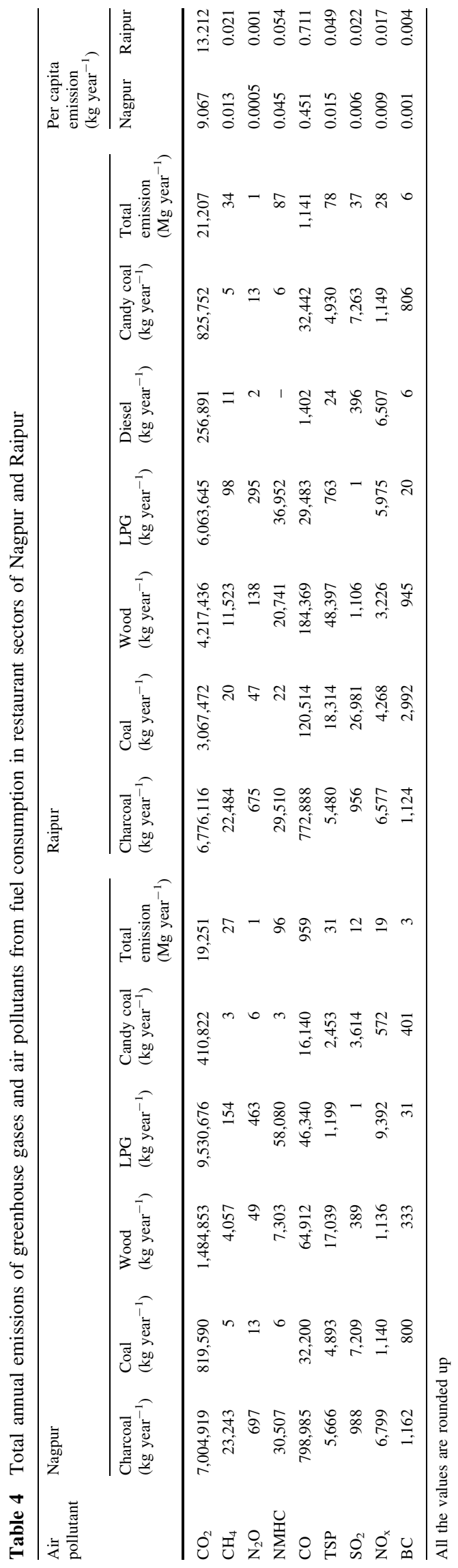

emission from fuel consumption in restaurant industry was comparatively higher in Raipur while $\mathrm{N}_{2} \mathrm{O}$ emissions were almost similar in both cities. Total greenhouse gas emission was more in Raipur, primarily driven by the usage of substantially higher quantity of coal, candy coal and wood.

Global warming commitment (GWC), i.e. the future warming which has not yet occurred, of $\mathrm{CH}_{4}$ and $\mathrm{N}_{2} \mathrm{O}$ in terms of $\mathrm{CO}_{2}$-equivalent emissions at various time horizons underlined their contribution to global warming in coming time horizons (Table 5). GWC was higher on 20-year time horizon for $\mathrm{CH}_{4}$ and 100-year time horizon for $\mathrm{N}_{2} \mathrm{O}$ as their respective global warming potential (GWP), i.e. the ratio of the radiative forcing that would result from the emission of $1 \mathrm{~kg}$ of a greenhouse gas to that from the emission of $1 \mathrm{~kg}$ of $\mathrm{CO}_{2}$ over a specific time period, were higher in these respective time horizons. GWC of $\mathrm{CH}_{4}$ and $\mathrm{N}_{2} \mathrm{O}$ emitted from charcoal were the highest amongst all due to sheer dominance of charcoal over other fuels in emissions of these two gases, followed by wood and LPG in both cities. GWC of $\mathrm{CH}_{4}$ was higher than $\mathrm{N}_{2} \mathrm{O}$ for charcoal and wood, whereas GWC of $\mathrm{N}_{2} \mathrm{O}$ emitted from coal, LPG and candy coal were higher than $\mathrm{CH}_{4}$ in Nagpur. In Raipur, global warming commitment of $\mathrm{CH}_{4}$ was higher than $\mathrm{N}_{2} \mathrm{O}$ for charcoal, wood and diesel, whereas for the other fuels it was the reverse. Percent contributions of different fuels in total $\mathrm{CO}_{2}$-eq. emissions over a 100-year time horizon in Nagpur were the following: charcoal $(74.5 \%)$, LPG $(14.1 \%)$, wood $(10.8 \%)$, coal $(0.4 \%)$ and candy coal $(0.2 \%)$. The same for Raipur were: charcoal $(63.4 \%)$, wood $(27 \%)$, LPG (8\%), coal (1.3\%), candy coal $(0.35 \%)$ and diesel $(0.07 \%)$.

\section{Non-greenhouse air pollutants}

Amongst all non-greenhouse air pollutants, $\mathrm{CO}$ emission was substantially higher than other pollutants in both the cities from all fuels except for diesel in Raipur due to higher $\mathrm{CO}$ emission factors reported for the fuels. Total $\mathrm{CO}$ emission from Raipur (1,141 $\mathrm{Mg}$ year $^{-1}$ ) was more than Nagpur (959 $\mathrm{Mg}$ year $^{-1}$ ), primarily influenced by high consumption and emission from coal and wood in the former. The major source of $\mathrm{CO}$ emission was charcoal in both cities followed by wood and LPG in Nagpur and wood and coal in Raipur. The share of various fuels towards total $\mathrm{CO}$ emission was highly variable ranging from 2 to $83 \%$ and from negligible to $68 \%$ in Nagpur and Raipur, respectively (Fig. 1). The contribution of coal was three times more, while wood had two times more contribution in total $\mathrm{CO}$ emission in Raipur than Nagpur. But, LPG had a two times higher share in CO emissions in Nagpur. Contribution of diesel was negligible in Raipur city at $0.13 \%$ (Fig. 1).

In Nagpur, LPG had highest contribution in NMHC and $\mathrm{NO}_{x}$ emissions, because of high emission coefficients and 
Fig. 1 Contribution of different fuels in annual emissions from restaurant sector of Nagpur and Raipur
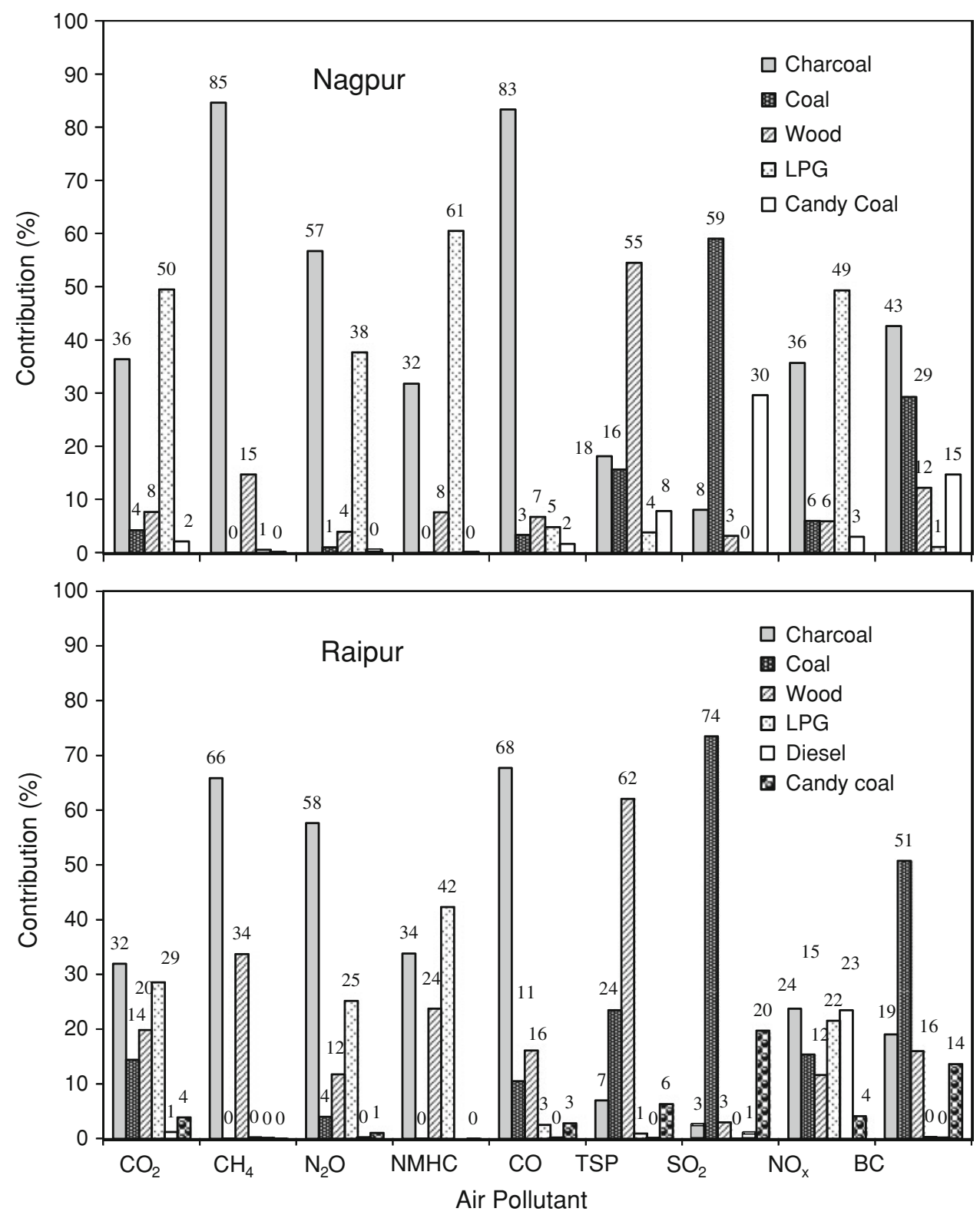

substantial LPG usage, followed by charcoal (Fig. 1). In Raipur, LPG had higher contribution than other fuels in NMHC emissions, because of higher EF and substantial usage while charcoal had highest contribution in $\mathrm{NO}_{x}$ emissions. The contribution of LPG in NMHC emissions were 61 and $42 \%$ in Nagpur and Raipur, respectively. Charcoal had second major share in NMHC emissions contributing $32 \%$ in Nagpur and $34 \%$ in Raipur (Fig. 1). Coal contributed to three times more NMHC emissions in Raipur. The emission contributions ranged from 6 to $51 \%$ for different fuels in Nagpur and 12 to $25 \%$ in Raipur.

In both the cities, coal had the highest contribution in $\mathrm{SO}_{2}$ emissions, as Indian coal has substantial amount of sulphur which contributes to $\mathrm{SO}_{2}$ formation during combustion. Contribution of different fuels in $\mathrm{SO}_{2}$ emissions ranged in between 0.01 and $59 \%$ in Nagpur, whereas in Raipur this range was slightly wider at $0.003-74 \%$. The highest emission contribution was from coal followed by wood and LPG in both the cities (Fig. 1). $\mathrm{SO}_{2}$ emissions hold a major importance in atmospheric chemistry, smog formation and acid rain formation and a significant reduction in $\mathrm{S}$ levels in fuels may reduce it emission significantly. Raipur emitted more than three times $\mathrm{SO}_{2}$ over Nagpur.

One of the major pollutants emitted by combustion of fuels particularly solid fuels like coal, charcoal and wood is suspended particulate matter. Wood combustion releases maximum total suspended particulates (TSP) and wood 
Table 5 Global warming commitment of $\mathrm{CH}_{4}$ and $\mathrm{N}_{2} \mathrm{O}$ (as $\mathrm{kg} \mathrm{CO}_{2}$-Eq) emitted in Nagpur and Raipur at different time horizons

\begin{tabular}{|c|c|c|c|c|c|c|c|c|c|}
\hline \multirow[t]{2}{*}{ Fuel } & \multicolumn{2}{|l|}{20 year } & \multirow{2}{*}{$\begin{array}{l}\text { Fuel Total } \\
\text { (kg CO} \text { (n-eq.) }^{2}\end{array}$} & \multicolumn{2}{|l|}{100 year } & \multirow{2}{*}{$\begin{array}{l}\text { Fuel Total } \\
\text { (kg CO} \text { (n-eq.) } \text { - }\end{array}$} & \multicolumn{2}{|l|}{500 year } & \multirow{2}{*}{$\begin{array}{l}\text { Fuel Total } \\
\text { (kg CO}{ }_{2} \text {-eq. }\end{array}$} \\
\hline & $\begin{array}{l}\mathrm{CH}_{4} \\
\left(\mathrm{~kg} \mathrm{CO}_{2} \text {-eq.) }\right.\end{array}$ & $\begin{array}{l}\mathrm{N}_{2} \mathrm{O} \\
\text { (kg CO}{ }_{2} \text {-eq.) }\end{array}$ & & $\begin{array}{l}\mathrm{CH}_{4} \\
\text { (kg CO} \mathrm{Kg}_{2} \text {-eq.) }\end{array}$ & $\begin{array}{l}\mathrm{N}_{2} \mathrm{O} \\
\text { (kg CO}{ }_{2} \text {-eq.) }\end{array}$ & & $\begin{array}{l}\mathrm{CH}_{4} \\
\text { (kg CO} \mathrm{CO}_{2} \text {-eq.) }\end{array}$ & $\begin{array}{l}\mathrm{N}_{2} \mathrm{O} \\
\text { (kg CO} \text { - }_{2} \text {-eq.) }\end{array}$ & \\
\hline \multicolumn{10}{|l|}{ Nagpur } \\
\hline Char coal & $1,441,066$ & 191,675 & 1632,741 & 534,589 & 206,312 & 740,901 & 162,701 & 108,732 & 271,433 \\
\hline Coal & 310 & 3,575 & 3,885 & 115 & 3,848 & 3,963 & 35 & 2,028 & 2,063 \\
\hline Wood & 251,534 & 13,475 & 265,009 & 93,311 & 14,504 & 107,815 & 28,399 & 7,644 & 36,043 \\
\hline LPG & 9,548 & 127,325 & 136,873 & 3,542 & 137,048 & 140,590 & 1,078 & 72,228 & 73,306 \\
\hline Candy coal & 186 & 1,650 & 1,836 & 69 & 1,776 & 1845 & 21 & 936 & 957 \\
\hline City Total & $1,702,644$ & 337,700 & $2,040,344$ & 631,626 & 363,488 & 995,114 & 192,234 & 191,568 & 383,802 \\
\hline \multicolumn{10}{|l|}{ Raipur } \\
\hline Charcoal & $1,394,008$ & 185,625 & $1,579,633$ & 517,132 & 199,800 & 716,932 & 157,388 & 105,300 & 262,688 \\
\hline Coal & 1,240 & 12,925 & 14,165 & 460 & 13,912 & 14,372 & 140 & 7,332 & 7,472 \\
\hline Wood & 714,426 & 37,950 & 752,376 & 265,029 & 40,848 & 305,877 & 80,661 & 21,528 & 102,189 \\
\hline LPG & 6,076 & 81,125 & 87,201 & 2,254 & 87,320 & 89,574 & 686 & 46,020 & 46,706 \\
\hline Candy coal & 310 & 3,575 & 3,885 & 115 & 3,848 & 3,963 & 35 & 2,028 & 2,063 \\
\hline Diesel & 682 & 550 & 1,232 & 253 & 592 & 845 & 77 & 312 & 389 \\
\hline City total & $2,116,742$ & 321,750 & $2,438,492$ & 785,243 & 346,320 & $1,131,563$ & 238,987 & 182,520 & 421,507 \\
\hline
\end{tabular}

Italics indicate to differentiate from others as former is city/fuel total

smoke is known to have approximately $80-90 \%$ of particulates (Bay Area Air Quality management District; http://www.baaqmd.gov/Divisions/Communications-andOutreach/Air-Quality-in-the-Bay-Area/Wood-Burning/ Wood-Burning-Rule-Information.aspx; accessed on 26.4. 2011) and wood has the highest TSP emission coefficient amongst the used fuels in this study. As coal and wood usage were substantially higher in Raipur, much higher TSP emission was generated from Raipur. Contribution of wood and coal were 55 and $16 \%$ in Nagpur while in Raipur contribution of wood was also appreciable, $62 \%$. In Nagpur though, contribution of charcoal was more than coal as usage of charcoal was substantially higher than coal here. Although LPG is a poor emitter of TSP, due to its huge consumption in Nagpur, it had $4 \%$ contribution to TSP emissions, approximately four times more than Raipur. Though TSP emissions from charcoal were almost similar in Nagpur and Raipur, charcoal had two times more contribution in TSP emissions compared to Raipur. Raipur emitted almost 61 times more TSP than Nagpur.

Black carbon emission from charcoal and coal was highest in Nagpur and Raipur, respectively. Biomass-based cookstoves have been held responsible by several studies for substantial black carbon emissions and even improved cookstoves may not minimize BC emissions (Bond and Sun 2005). Coal had contributed $51 \%$ in BC emissions in Raipur, whereas in Nagpur its contribution was only $29 \%$. In Nagpur, charcoal had highest contribution (43\%) to BC emissions, because of its comparatively higher consumption than coal or wood, though it is a cleaner fuel than the two. LPG's contribution was low in both cities and in
Nagpur it had three times more contribution in BC emissions than Raipur due to much higher consumption in the former. Total BC emission was two times more in Raipur than Nagpur. Comparative contribution of different fuels towards emissions of the greenhouse gases and air pollutants has been summarized in Table 6 , which indicates that charcoal and LPG dominated in most cases over other fuels in terms of their contribution towards majority of pollutants since their usage were substantially higher in many cases than others, particularly in Nagpur.

Per capita emissions

Per capita emission is an important indicator of air pollution potential of a city or a country or a sector, as air pollution is integrally associated with increasing population and consequently energy consumption. Per capita emission is considered an important benchmark for comparison between cities or countries or sectors. Raipur had 1.3-5 times more per capita fuel consumption except LPG and 1.2-4 times more per capita emission of air pollutants including greenhouse gases (1.5-2 times) than Nagpur across all the fuel types. Since there is no database on actual number of people dining in restaurants in a year in these cities, per capita fuel consumption and emission were calculated on total city population. Per capita consumption and emission would have certainly been much higher if only diner population was used for the calculation, as it is generally assumed that only a part of total city population may be dining outside, though this fraction is unknown. As the restaurant industry is growing, total emissions of 
Table 6 Contribution of different fuels to annual emissions

\begin{tabular}{|c|c|c|c|c|}
\hline \multirow[t]{2}{*}{ Pollutant } & \multicolumn{2}{|l|}{ Within city } & \multicolumn{2}{|c|}{ Between cities ${ }^{b}$} \\
\hline & Nagpur $^{\mathrm{a}}$ & Raipur $^{\mathrm{a}}$ & Nagpur & Raipur \\
\hline $\mathrm{CO}_{2}$ & $\begin{array}{l}\text { LPG }>\text { charcoal }>\text { wood }>\text { coal }>\text { candy } \\
\text { coal }\end{array}$ & $\begin{array}{l}\text { Charcoal }>\text { LPG }>\text { wood }>\text { coal }>\text { candy } \\
\text { coal }>\text { diesel }\end{array}$ & $\begin{array}{l}\text { Charcoal, } \\
\text { LPG }\end{array}$ & $\begin{array}{l}\text { Wood, coal, candy } \\
\text { coal }\end{array}$ \\
\hline $\mathrm{CH}_{4}$ & $\begin{array}{l}\text { Charcoal }>\text { wood }>\text { LPG }>\text { coal }>\text { candy } \\
\text { coal }\end{array}$ & $\begin{array}{l}\text { Charcoal }>\text { wood }>\text { LPG }>\text { coal }>\text { diesel }>\text { candy } \\
\text { coal }\end{array}$ & & \\
\hline $\mathrm{N}_{2} \mathrm{O}$ & $\begin{array}{l}\text { Charcoal }>\text { LPG }>\text { wood }>\text { coal }>\text { candy } \\
\text { coal }\end{array}$ & $\begin{array}{l}\text { Charcoal }>\text { LPG }>\text { wood }>\text { coal }>\text { candy } \\
\text { coal }>\text { diesel }\end{array}$ & & \\
\hline NMHC & $\begin{array}{l}\mathrm{LPG}>\text { charcoal }>\text { wood }>\text { coal }>\text { candy } \\
\text { coal }\end{array}$ & LPG $>$ charcoal $>$ wood $>$ coal $>$ candy coal & & \\
\hline $\mathrm{CO}$ & $\begin{array}{l}\text { Charcoal }>\text { wood }>\text { LPG }>\text { coal }>\text { candy } \\
\text { coal }\end{array}$ & $\begin{array}{l}\text { Charcoal }>\text { wood }>\text { coal }>\text { candy } \\
\text { coal }>\text { LPG }>\text { diesel }\end{array}$ & & \\
\hline TSP & $\begin{array}{l}\text { Wood }>\text { charcoal }>\text { coal }>\text { candy } \\
\text { coal }>\text { LPG }\end{array}$ & $\begin{aligned} \text { Wood } & >\text { coal }>\text { charcoal }>\text { candy } \\
\text { coal } & >\text { LPG }>\text { diesel }\end{aligned}$ & & \\
\hline $\mathrm{SO}_{2}$ & $\begin{array}{l}\text { Coal }>\text { candy } \\
\text { coal }>\text { charcoal }>\text { wood }>\text { LPG }\end{array}$ & $\begin{array}{l}\text { Coal }>\text { candy } \\
\text { coal }>\text { wood }>\text { charcoal }>\text { diesel }>\text { LPG }\end{array}$ & & \\
\hline $\mathrm{NO}_{\mathrm{x}}$ & $\begin{array}{l}\text { LPG }>\text { charcoal }>\text { coal }>\text { wood }>\text { candy } \\
\text { coal }\end{array}$ & $\begin{array}{l}\text { Charcoal }>\text { diesel }>\text { LPG }>\text { coal }>\text { wood }>\text { candy } \\
\text { coal }\end{array}$ & & \\
\hline $\mathrm{BC}$ & $\begin{array}{l}\text { Charcoal }>\text { coal }>\text { candy } \\
\text { coal }>\text { wood }>\text { LPG }\end{array}$ & $\begin{array}{l}\text { Coal }>\text { charcoal }>\text { wood }>\text { candy } \\
\text { coal }>\text { LPG }>\text { diesel }\end{array}$ & & \\
\hline
\end{tabular}

a Fuels are arranged in descending order in terms of emissions

b Fuels mentioned under a city had contributed to more emissions in the city than the corresponding fuels in the other city. Diesel was not considered for comparison between cities as it was not under usage in restaurant sector of Nagpur

pollutants would certainly increase in these cities vis-a-vis India, but per capita emission may or may not change drastically depending on population growth.

\section{Conclusion}

Total emissions of greenhouse gases and other air pollutants, except $\mathrm{N}_{2} \mathrm{O}$ and NMHC, were more in Raipur than Nagpur in the study year of 2010. More usage of highly emitting fuels like wood and coal influenced higher emissions of these few pollutants in Raipur and to offset this trend, large-scale replacement of these fuels with cleaner LPG is necessary. Higher usage of coal in Raipur seems to have been largely driven by abundance of coal supply in this industrial city where a large number of sponge iron, rolling mills, ferro-alloy and captive power plants are operating, all of which use substantial quantity of coal. Much higher per capita income in Maharashtra than Chattisgarh (Department of Planning, Government of Punjab, http://pbplanning.gov.in/pdf/Statewise $\% 20$ Per\%20 Capita\%20Income\%20\%20Current.pdf; accessed on 23.5. 2011) may have played an important role in influencing the fuel usage, tilting it in favour of more expensive but cleaner LPG in restaurant industry. Though number of registered restaurants per unit area was higher in Raipur (total area: $180 \mathrm{~km}^{2} ; 2.85$ restaurants $/ \mathrm{km}^{2}$ ) than Nagpur (total area: $218 \mathrm{~km}^{2} ; 2.61$ restaurants $/ \mathrm{km}^{2}$ ) as per the data collected during this study, this may not ensure better infrastructure, investment and facility in this sector in the former. Being an industrial town, Raipur justifies the presence of more number of restaurants per unit area as industrial workforce and population in transit may constitute a major chunk of diners.

Though the growth of restaurant industry in India has been predicted in financial terms, projections on usage of various fuel types by this sector has not been done yet. There may not be any doubt that along with growing investment in this sector, the number of restaurants and fuel usage will also increase, but region-wise distribution of fuel and their likely magnitude of usage in restaurant industry are difficult to predict. With increasing growth of Indian restaurant industry, availability and supply of a clean fuel like LPG has to also grow to stabilize or reduce the emission levels from this industry. But, future growth in supply of LPG in the restaurant industry may be under cloud in the scenario of increasing demand, restricted production and supply and escalating cost. The production of petroleum products during 2009-2010 was 151.898 million metric tonnes (mMT) which included $2.244 \mathrm{mMT}$ of LPG from natural gas, registering a decrease of $0.51 \%$ over last year's production at $152.678 \mathrm{mMT}$ including $2.162 \mathrm{mMT}$ of LPG (Ministry of Petroleum and Natural Gas 2010). It is also difficult to project fuel usage in 
restaurant industries of other cities in India based on Nagpur and Raipur experience, as Indian cities are variable in terms of area, spending power, food habit, culture of eating outside, etc., giving every city its very unique identity and emission potential. To calculate an all India emission inventory from restaurant industry, creating an all India database on registered restaurants and their fuel consumption will have to be undertaken and this study may be a stimulant in that direction.

Acknowledgments Authors thank Director, NEERI, for his constant encouragement and guidance.

\section{References}

Ballard-Tremeer G (1997) Emissions of rural wood-burning cooking devices. Ph.D. Thesis, School of Mechanical Engineering, University of the Witwatersrand, Johannesburg-2050, South Africa

Ballard-Tremeer G, Jawurek HH (1996) Comparison of five rural wood-burning cooking devices: efficiencies and emissions. Biomass Bioenerg 11:419-430

Bhattacharya SC, Abdul Salam P, Sharma M (2000) Emissions from biomass energy use in some selected Asian countries. Energy 25:169-188

Bhattacharya SC, Albina DO, Abdul Salam P (2002) Emission factors of wood and charcoal-fired cookstoves. Biomass Bioenerg 23(6):453-469

Bhonsle KD (2010) A study of urbanization in Nagpur district. Inst Town Plan India J 7-3:88-95

Bond TC, Sun H (2005) Can reducing black carbon emissions counteract global warming? Environ Sci Tech 39(16):5921-5926

Census of India (2001) Government of India, India

Chaiklangmuang S, Chotchaitanakorn Y, Sri-phalang S (2008) Feasibility survey of fuel briquette demands in roasting food restaurants in Chiang Mai Province, Thailand. Chiang Mai J Sci 35(1), 51-55. (http://www.science.cmu.ac.th/journal-science/ 351_09FeasiSuparin.pdf)

Donaldlucas L, Fischer SL, Lee SC, Katharineha S, Mond M, Koshland C (2008) Particle and gas emissions from a simulated coal-burning household fire pit. Environ Sci Tech 42:2503-2508

Eastern Research Group (1996) Report on revisions to 5th edition AP42 (Section 3.3): gasoline and diesel industrial engines. Prepared for U.S. Environmental Protection Agency, USA, p 74

Energy Information Administration (2001) Updated state-level greenhouse gas emission factors for electricity generation. Energy Information Administration, USA, p 12

Federation of Hotels and Restaurant Associations of India (2004) Restaurant industry in India-trends and Opportunities. Federation of Hotel \& Restaurant Associations of India (FHRAI), New Delhi, p 64

Financial Chronicle (2010) Restaurant market to touch Rs 28,000 cr. Date: 10-05-2010, Delhi Edition, p 6. (http://www.nrai.org/ news.asp; retrieved on 28.5.2012)

Garg A, Shukla PR (2002) Emission Inventory of India. Tata McGraw Hill Publishing Company Ltd, New Delhi, p 56

Garg A, Shukla PR, Bhattacharya S, Dadhwal VK (2001) Sub-region (district) and sector level $\mathrm{SO}_{2}$ and $\mathrm{NO}_{x}$ emissions for India: assessment of inventories and mitigation flexibility. Atmos Environ 35:703-713

Garg A, Shukla PR, Kapshe M (2006) The sectoral trends of multigas emissions inventory of India. Atmos Environ 40:4608-4620
IPCC (1997) Guidelines for National Greenhouse Gas Inventories: Reference Manual (rev. 1996) vol. 3, United Kingdom: Blacknell

IPCC (2001) Climate change 2001: a scientific basis, Intergovernmental Panel on climate change. Cambridge University Press, Cambridge

IPCC (2006) 2006 IPCC Guidelines for National Greenhouse Gas Inventories, vol. 2: Energy. National Greenhouse Gas Inventories Programme, IGES, Japan

Kabir E, Kim KH, Ahn JW, Hong OF, Sohn JR (2010) Barbecue charcoal combustion as a potential source of aromatic volatile organic compounds and carbonyls. J Haz Mat 174:492-499

Ministry of Environment and Forests (2010) India: Greenhouse Gas Emissions 2007. Ministry of Environment and Forests, Government of India, New Delhi, India, p 84 (http://moef.nic.in/ downloads/public-information/Report_INCCA.pdf)

Ministry of Petroleum and Natural Gas (2010) Basic Statistics on Indian Petroleum \& Natural Gas 2009-10. Government of India, New Delhi

Pandey D (2002). Fuelwood Studies in India: Myth and Reality. Centre for International Forestry Research, Indonesia, p 108

Parashar DC, Gadi R, Mandal TK, Mitra AP (2005) Carbonaceous aerosol emissions from India. Atmos Environ 39:7861-7871

Pearson PN, Palmer MR (2000) Atmospheric carbon dioxide concentrations over the past 60 million years. Nature 406:695-699

Pinnium N (2000) Production and acceptation of using of solid fuel and green fuel in rural: case study of Amphur Klonghuang, Patumtanee province. Sci Tech J 2:45-50

Rand J, Scatena L (2006) Workgroup recommendations and other potential control measures from the homes and restaurant workgroup. HR010-restaurant controls. White Paper prepared for New Jersey Department of Environmental Protection, USA (http://www.state.nj.us/dep/baqp/rapt/wps/HR010_fin.pdf)

Reddy MS, Venkataraman C (2002a) Inventory of aerosol and sulphur dioxide emissions from India. Part II-biomass combustion. Atmos Environ 36:699-712

Reddy MS, Venkataraman C (2002b) Inventory of aerosol and sulphur dioxide emissions from India: I Fossil fuel combustion. Atmos Environ 36:677-697

Smith KR, Uma R, Kishore VVN, Lata K, Joshi V, Zhang J, Rasmussen RA, Khalil MAK (2000) Greenhouse gases from small-scale combustion devices in developing countries: Phase IIA, Household stoves in India. EPA-600/R-00-052. Office of Research and Development, US EPA, Washington, DC 20460

Standing Committee on Energy (2001) Chapter VI: Quality/price/ import of coal (http://164.100.24.208/1s/committeeR/Energy/ 18th/chapter6.htm, accessed on 30.6.2010)

Suntisirisomboon J, Milintale J (2001) Environmental effect from biomass energy uses. Energ Effic J 52:22-25

TERI (1992) Environmental effects of energy production, transformation and consumption in NCR. Tata Energy Research Institute, New Delhi

Tiwary RK, Dhar BB (1994) Environmental pollution from coal mining activities in Damodar river basin, India. Mine Water Environ 13:1-10

Treanton K (2004) Net calorific values. Special issue paper 8, IEA, Energy Statistics Division, Energy Statistics Working Group Meeting, 16-17 November, IEA, Paris (http://www.iea.org/ work/2004/eswg/21_NCV.pdf, retrieved on 30.6.2010)

US Dept of Energy (1995) Appendix EA.1. Emission factors for combustion from natural gas, LPG, and oil-fired residential water heaters and clothes dryers

USEPA (2000a) Greenhouse gases from small-scale combustion devices in developing countries: Phase II A: Household stoves in 
India (USEPA/600/r-00/052; www.epa.gov/nrmrl/pubs/600r00052/ 600R00052.pdf, retrieved on 30.6.2010)

USEPA (2000b) AP 42 (5th edn). Compilation of air pollutant emission factors, vol. 1: Stationary point and area sources, USEPA, USA (http://www.epa.gov/ttn/chief/ap42/ch01/final/ c01s07.pdf)
West JJ, Fiore AM, Horowitz LW, Mauzerall DL (2006) Global health benefits of mitigating ozone pollution with methane emission controls. PNAS 103(11):3988-3993

Zhang J, Smith KR (2007) Household air pollution from coal and biomass fuels in China: measurements, health impacts, and interventions. Environ Health Perspect 115(6):851-853 